\title{
Causes of anemia in pregnant women of the State of Azad Kashmir: A cross-sectional survey
}

\author{
Atif Abbasi $^{1}$, Sheeba Arooj ${ }^{2}$, Wafa Hussain ${ }^{2}$, Asif Iqbal Mughal $^{2}$, Nazneen Habib ${ }^{2}$, \\ Wajid Aziz ${ }^{3}$, Muhammad Rafique ${ }^{4^{*}}$ \\ ${ }^{1}$ Department of Statistics, University of Azad Jammu \& Kashmir, Muzaffarbad, Pakistan \\ ${ }^{2}$ Department of Sociology and Rural Development, University of Azad Jammu \& Kashmir, City Campus, Muzaffarabad, Pakistan \\ ${ }^{3}$ Department of CS \& IT, University of Azad Jammu \& Kashmir, City Campus, Muzaffarabad, Pakistan \\ ${ }^{4}$ Department of Physics, University of Azad Jammu \& Kashmir, Azad Kashmir, Pakistan; \\ *Corresponding Author: rafi_722002@yahoo.com, mrafique@gmail.com
}

Received 5 November 2012; revised 10 December 2012; accepted 18 December 2012

\section{ABSTRACT}

Background: Epidemic of anemia is considered to be a significant threat to pregnant women or women in child bearing age. Anemia is one of the major nutritional health disorders affecting significant proportion of population not only in developing countries but also in developed countries. This threat is more alarming in developing countries where poverty, illiteracy may contribute to high risk for causes of anemia. Objective: The purpose of the current study was to investigate the main causes of anemia in pregnant women in the State of Azad Kashmir, Muzaffarabad and to investigate the relationship between education and anemia. Methods: A descriptive cross sectional study was conducted over a sample of 433 pregnant women. The Chisquare test has been used to assess the statistical significance of different risk factors with $\mathrm{Hb} \%$ (Heamoglobin) of the respondent. The multiple logistic regression model was used to get the most significant risk factors of anemia. Results: The study shows that the most dominant risk factors of the anemia were age at the time of marriage at different age categories that are $16-20$ (OR = 3.945) (OR Odds ratios) with 95\% C-I (confidence interval) (0.294 to 52.985), $21-25$ (OR = 2.316) with 95\% C-I (0.192 to 27.932) and $26-30$ (OR $=4.179)$ with $95 \%$ C-I (0.347 to 50.320). Education at different education levels that is illiterate $(O R=1.191)$ with $95 \%$ C-I $(0.005$ to 87.279$)$ and primary $(O R=1.179)$ with $95 \% \mathrm{C}-\mathrm{I}$ (0.009 to 156.200$)$. $\mathrm{Hb} \%$ at different levels $3-4$ g/dl (OR $=1.220$ ) with $95 \%$ C-I (0.299 to 4.984), 5 $6 \mathrm{~g} / \mathrm{dl}$ (OR $=2.221)$ with $95 \% \mathrm{C}-\mathrm{I}(0.679$ to7.263) and $7-10 \mathrm{~g} / \mathrm{dl}(\mathrm{OR}=1.384)$ with $95 \% \mathrm{C}-\mathrm{I}$ (0.408 to
4.689). Monthly income $<10,000(O R=2.296)$ 95\% C-I (0.385 to 13.677), 11,000 - 15,000 (OR = $3.623) 95 \%$ C-I (0.678 to 19.31) and 16,000 to $20,000$ (OR $=2.158) 95 \%$ C-I (0.441 to 10.563). Age of last child born 1 year (OR $=1.711) 95 \% \mathrm{C}$-I (0.399 to 7.341), 2 years (OR $=1.284) 95 \% \mathrm{C}-\mathrm{I}$ ( 0.304 to 5.421 ) and $<1$ year (OR $=2.224$ ) $95 \%$ C-I (0.552 to 8.952). Daily eating habits, just like previous (OR $=2.415$ ) $95 \% \mathrm{C}-\mathrm{I}(0.652$ to 8.948$)$, less than previous $(O R=3.671) 95 \% \mathrm{C}-\mathrm{I}(0.868$ to 15.522). Previous history of miscarriage (OR = 1.258) $95 \%$ C-I ( 0.103 to 0.647$)$, suffered in any hemorrhagic disease (OR $=1.529)$ 95\% C-I (0.592 to 3.949). Nature of the work Exhaustive (OR = $1.961) 95 \%$ C-I (0.805 to 4.779$)$.

Keywords: Odd Ratio; Logistic Regression; Anemia; Chi-Square; Pregnant Women

\section{INTRODUCTION}

Anemia is one of the major nutritional deficiency health disorders, affecting significant proportion of population. Although it effects all age groups but it is most prevalent in pregnant women. Anemia is pathological deficiency in oxygen carrying capacity of blood measured in hemoglobin concentration, red blood cells numbers. Blood is mainly composed of two parts 1) Plasma, constituting $55 \%$ of blood and 2) White blood cells, red blood cells \& platelets.

Common causes of anemia are dietary deficiencies, inherited genetic defects, side effects of medicine, chronic diseases, blood loss from injuries and internal bleeding, destruction of red blood cells or insufficient red blood cells production. Causes of anemia depend upon its severity the more severe the anemia is the more likely the 
chances of multiple reasons of anemia. Iron deficiency anemia is more common in pregnant because of increased need of iron for growing fetus. Women who start their pregnancy with low stored iron are at great risk to become anemic during the course of pregnancy.

Anemia is even common nutritional disorder of Industrialized nations but they have coped anemia through dietary improvement, prevention from malaria and improved technology. Anemia can be prevented by interventions of low cost like iron supplementation malarial prophylaxis and deworming [1].

Series of studies conducted in different parts of world shows that anemia is direct cause of $1 \%$ to $46 \%$ of maternal deaths [2].

In developing countries, causes of anemia in pregnancy are multifactorial. In pregnant women iron and folate deficiency anemia are common. These are related with nutritional deprivation intestinal worm infection. Hemolytic anemia is most common in malarial regions of developing countries. Severity of anemia can be greatly reduced by regularly prophylaxis of anemia during pregnancy [3].

\section{Situation in Pakistan}

Anemia particularly iron deficiency anemia is common in females of child bearing age and pregnant women in Pakistan. One of the findings of the study was that the anemia in Pakistan is more common in low socioeconomic group. Research conducted on selected anemic patients revealed that iron deficiency anemia is more common and risk factors of iron deficiency anemia are pregnancy (57\%), nutritional inadequacy (36\%) and others (7\%) [4].

According to UNO pregnant women of low-income group have $56 \%$ anemia. Dietary habits of pregnant women affect the hemoglobin level. Anemia is also associated with parity \& gravidity of women. $82.10 \%$ diagnosed anemic pregnant women were those who have poor dietary intake [5].

Study shows that about $15 \%$ of pregnant women experiences medical \& obstetric complication. MMR (Maternal mortality rate) is 276 per 100,000 births annually. This can be reduced by poverty reduction and empowerment of women [6].

Anemia is more common in Pakistan, particularly in women with no previous antenatal checkup and it is more common in women of low socioeconomic group. In urban areas of Pakistan 90.5\% of pregnant women were anemic among them $0.7 \%$ were severely anemic [7].

The anemia in pregnant women is directly associated with nutritional deprivation moreover it is associated with low socioeconomic status and educational level [8].

It was recommended that to reduce anemia education is vital if we really want to break dietary ignorance affecting significant number of population residing in rural areas where there nutritious food are in abundant quantity and they sell it in very low price [9].

Current study aimed at finding out the contributory factors of anemia in pregnant women due to some physiological changes and many other possible reasons.

\section{METHODOLOGY}

A descriptive cross sectional study was conducted in Muzaffarabad district after approval by the Ministry of public education in Azad Jammu \& Kashmir Muzaffarabad. A sample of 433 pregnant women based on convenient sampling technique was taken (women that visited hospital Abbas Institute of Medical Sciences (AIMS).

\subsection{Data Collection}

An epidemiological questionnaire was developed. The questionnaires were distributed to well train staff nurses who collected the information from the women in period of one month or more. The questionnaires were filled by face to face interview. Close ended questionnaire was used and level was that of for layman's understanding. A non probability sampling technique (Convenience Sampling) was used to collect the data.

\subsection{Ethical Approval}

This study was approved by the authorities of the Ministry of public education Azad Jammu \& Kashmir.

\subsection{Inclusion and Exclusion Criteria}

The inclusion criterion was only choosing pregnant women for the survey on the other hand all non-pregnant women were excluded from the current study.

\subsection{Analysis}

Data were entered in a spread sheet and analyzed using the SPSS software version 16. The descriptive statistics was used to check the response regarding causes of anemia. The Chi-square test was used to check the association between dependent variable ( $\mathrm{Hb} \%)$ and independent variables and the Multiple Logistic Regression model was performed to find out the most significant risk factors of anemia.

\section{RESULTS AND DISCUSSION}

As discussed earlier that sample size of 433 pregnant women were selected for the current study. A questionnaire was distributed among them (see Table 1). These women were classified on the basis of their educational level i.e. illiterate, primary, middle, matric and interme- 
Table 1. Questionnaire about causes of anemia in pregnant women.

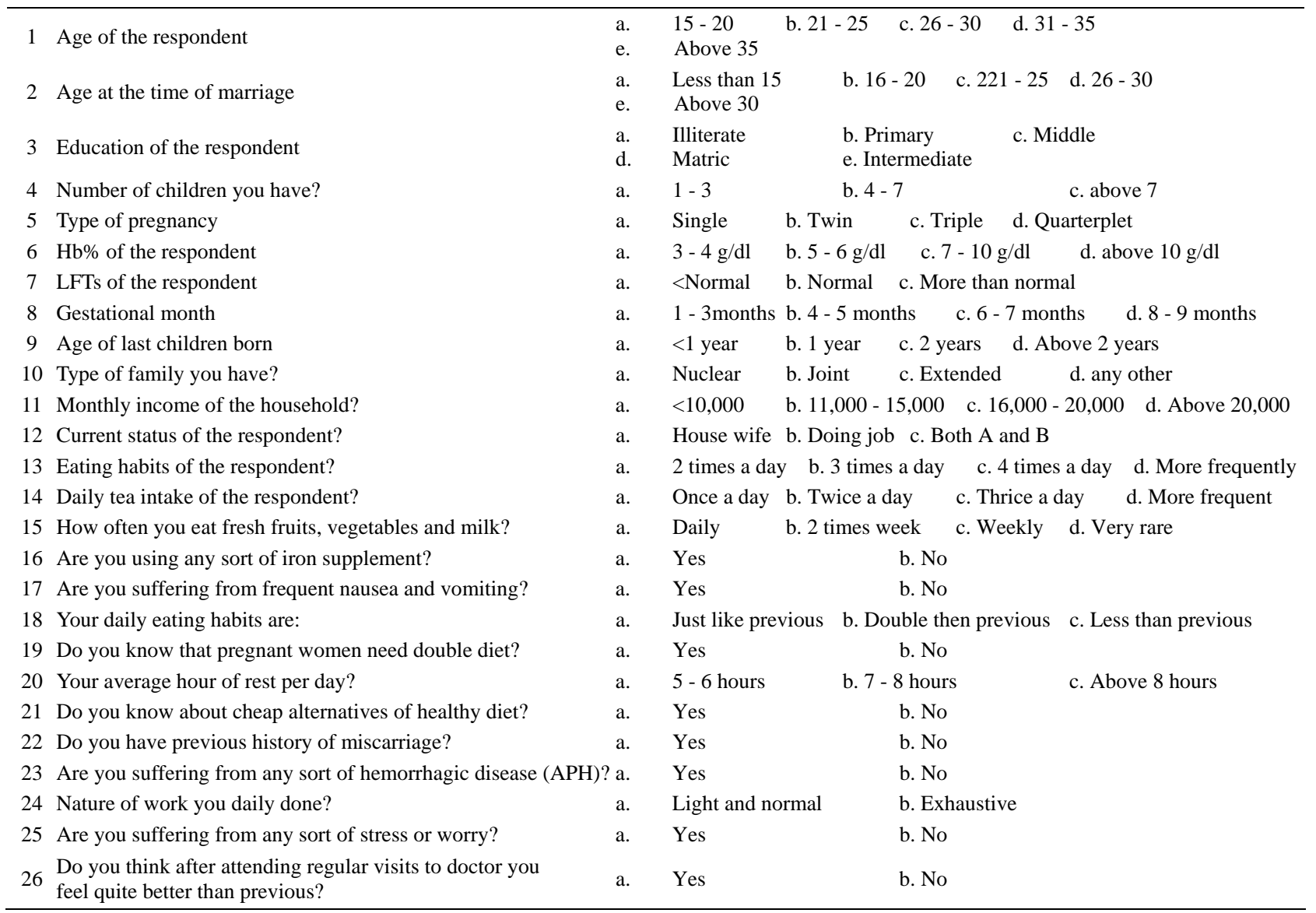

diate. Majority of the respondent (42.5\%) were illiterate, $25.9 \%$ were having primary education, $19.2 \%$ were of middle level, $11.3 \%$ were matric and $1.2 \%$ were of intermediate level (see Table 2).

A relationship between education level and anemia has been investigated. It was observed that there is almost linear but negative relationship between different education level and disease of anemia i.e. as education level decreases incidence of anemia increases (see Figure 1). In present study it was observed that anemia is more prevalent in women of low educational level. This may be attributed due to lack of knowledge of illiterate women. We have also investigated causes of anemia in pregnant women. To check the association of $\mathrm{Hb} \%$ with different variables the chi-square test was applied. Results showed that all the variables are strongly associated with $\mathrm{Hb} \%$ of the respondent only three of them have not shown association with $\mathrm{Hb} \%$ that are (previous history of miscarriage, suffered in frequent nausea and vomiting and suffered in any hemorrhagic disease) each of these three have p-value $>0.05$ the level of significance. And all the remaining variables showed highly association with $\mathrm{Hb} \%$ of the respondents that is each of these have p-value $<0.05$ the level of significance (as can be seen
Table 2. Frequency of different education level of the respondents.

\begin{tabular}{ccc}
\hline & Frequency & Percentage (\%) \\
\hline Illiterate & 184 & 42.5 \\
Primary & 112 & 25.9 \\
Middle & 83 & 19.2 \\
Matric & 49 & 11.3 \\
Intermediate & 5 & 1.2 \\
Total & $\mathbf{4 3 3}$ & $\mathbf{1 0 0 . 0}$ \\
\hline
\end{tabular}

from Table 3), which indicate that they are strongly associated with $\mathrm{Hb} \%$ of the respondents.

In order to take the feedback of pregnant women regarding causes of anemia, a questionnaire was distributed among them. Feedback of the pregnant women is mentioned in the Table 4. It can be seen from the Table 4 , that $40.2 \%$ of the respondents were in the age group of 26 - 30 years, $11.2 \%$ in the age group of 15 - 20 years, $21 \%$ in the age group 21 - 25 years whilst $16.4 \%$ and $10.6 \%$ were in the age category of 31 - 35 and above 35 years respectively.

About $18.2 \%$ of the respondents have $\mathrm{Hb} \%$ level between 3 - 4 g/dl, 21\% between 5 - 6 g/dl, 34.2\% between 


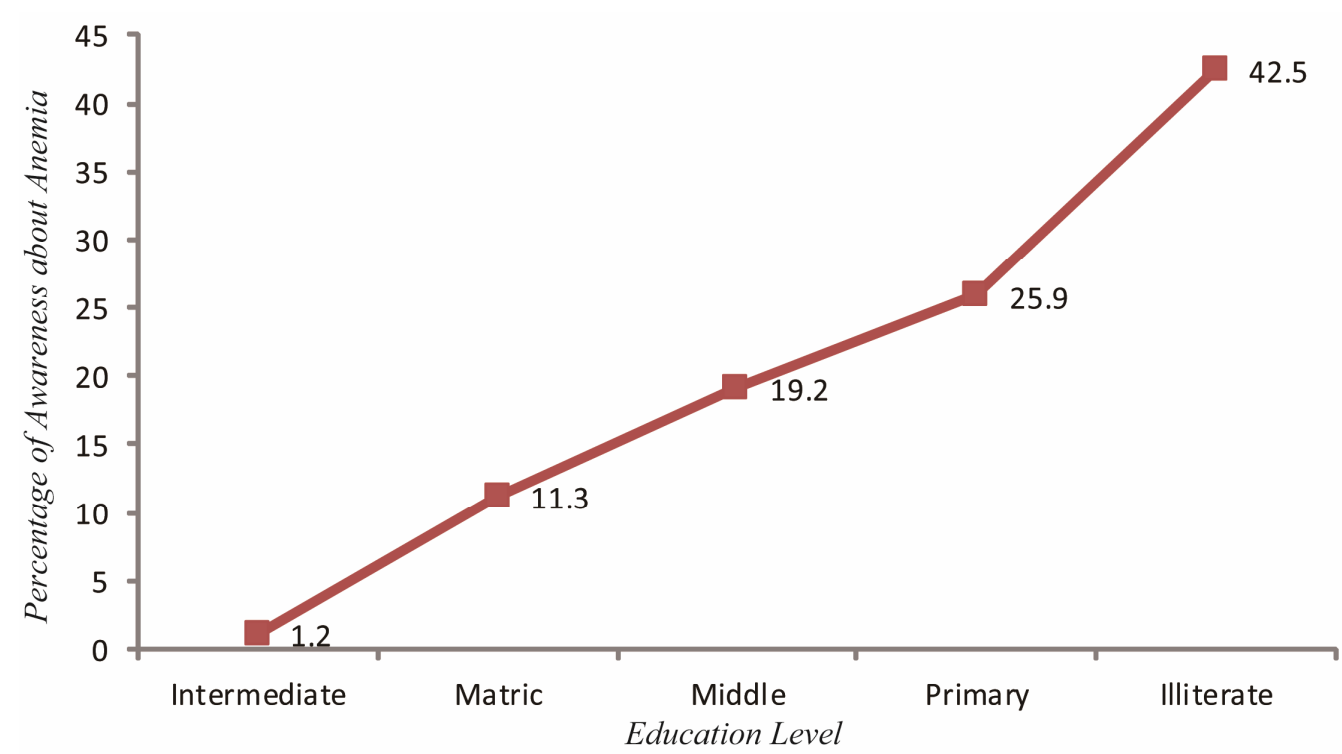

Figure 1. Respondent education level and trend of anemia.

Table 3. Results of Chi-square test for association of $\mathrm{Hb} \%$ with different variables.

\begin{tabular}{|c|c|c|}
\hline Variables & Chi-square value & p-value \\
\hline Hb\% of the respondent $*$ age & 80.550 & 0.000 \\
\hline $\mathrm{Hb} \%$ of the respondent $*$ age at the time of marriage & 53.907 & 0.000 \\
\hline $\mathrm{Hb} \%$ of the respondent * education of the respondent & 60.113 & 0.000 \\
\hline $\mathrm{Hb} \%$ of the respondent * no. of children you have? & 57.584 & 0.000 \\
\hline Hb\% of the respondent * type of pregnancy & 1.7962 & 0.000 \\
\hline $\mathrm{Hb} \%$ of the respondent * LFTs of the respondent & 33.563 & 0.000 \\
\hline Hb\% of the respondent $*$ Gestational month & 88.485 & 0.000 \\
\hline $\mathrm{Hb} \%$ of the respondent $*$ age of last child born & 69.142 & 0.000 \\
\hline $\mathrm{Hb} \%$ of the respondent * type of family you have? & 21.339 & 0.011 \\
\hline $\mathrm{Hb} \%$ of the respondent * Monthly income of the household? & 62.354 & 0.000 \\
\hline $\mathrm{Hb} \%$ of the respondent $*$ current status of the respondent & 34.365 & 0.000 \\
\hline Hb\% of the respondent * eating habits of the respondent & 39.991 & 0.000 \\
\hline $\mathrm{Hb} \%$ of the respondent * daily tea intake of the respondent & 27.116 & 0.001 \\
\hline $\mathrm{Hb} \%$ of the respondent * you are eating fresh fruits, vegetables and milk & 74.408 & 0.000 \\
\hline $\mathrm{Hb} \%$ of the respondent $*$ you are using any sort of iron supplement & 37.755 & 0.000 \\
\hline $\mathrm{Hb} \%$ of the respondent * are you suffering from frequent nausea and vomiting & 4.809 & 0.186 \\
\hline $\mathrm{Hb} \%$ of the respondent $*$ your daily eating habits are & 12.457 & 0.053 \\
\hline Hb\% of the respondent * do you know that pregnant vomen need for double diet & 25.667 & 0.000 \\
\hline $\mathrm{Hb} \%$ of the respondent * your average hour of rest per day & 1.0512 & 0.000 \\
\hline Hb\% of the respondent * do you know about cheap alternatives of healthy diet? & 24.697 & 0.000 \\
\hline $\mathrm{Hb} \%$ of the respondent $*$ do you have previous history of miscarriage? & 2.097 & 0.552 \\
\hline $\mathrm{Hb} \%$ of the respondent * are you suffering from any hemorrhagic disease (APH)? & 6.799 & 0.079 \\
\hline $\mathrm{Hb} \%$ of the respondent $*$ nature of work you daily done & 18.756 & 0.000 \\
\hline $\mathrm{Hb} \%$ of the respondent * are you suffering from any sort of stress or worry? & 27.987 & 0.000 \\
\hline $\begin{array}{l}\text { Hb\% of the respondent } * \text { what do you think after attending } \\
\text { regular visits to doctor you feel quite better then previous? }\end{array}$ & 16.294 & 0.001 \\
\hline
\end{tabular}

7 - $10 \mathrm{~g} / \mathrm{dl}$ and about 26.6\% have Hb\% level above 10 $\mathrm{g} / \mathrm{dl}$. lft of the respondents at different level was $24 \%$ having less than normal, majority of the respondents (68\%) had normal lft and 7.6\% respondents had more than normal lft. Gestational months of the respondents were 1 - 3 months (21.2\%), 4 - 5 months (27\%), 6 - 7 months (19.2\%), and 8 - 9 months (32.6\%). Most of the women $(40 \%)$ had last child born age less than 1 year, $24.2 \%$ respondents with 1 year, $22.6 \%$ with 2 years and $13.2 \%$ have more than 2 years. $43 \%$ of the women were belonged to nuclear family, $39 \%$ joint, $11.1 \%$ extended family and $6.9 \%$ were belonged to any other family. 
Table 4. Response of respondents about causes of anemia in pregnant women.

\begin{tabular}{|c|c|c|c|c|}
\hline & Questions & & n perc & \\
\hline & & $15-20$ & 51 & 11.8 \\
\hline & & $21-25$ & 91 & 21.0 \\
\hline Age & & $26-30$ & 174 & 40.2 \\
\hline & & $31-35$ & 71 & 16.4 \\
\hline & & above 35 & 46 & 10.6 \\
\hline & & Less than 15 years & 75 & 17.3 \\
\hline & & $16-20$ years & 238 & 55.0 \\
\hline Age at the time of marriage & & $21-25$ years & 75 & 17.3 \\
\hline & & $26-30$ years & 33 & 7.6 \\
\hline & & above 30 years & 12 & 2.8 \\
\hline & & $1-3$ & 203 & 46.9 \\
\hline No. of children you have? & & $4-7$ & 116 & 26.8 \\
\hline & & above 7 & 114 & 26.3 \\
\hline & & single & 270 & 62 \\
\hline Tyme of proqnongy & & Twin & 92 & 21.2 \\
\hline 1ype or pregnancy & & Triple & 67 & 15.5 \\
\hline & & Quarterplet & 04 & 0.9 \\
\hline & & $3-4 \mathrm{~g} / \mathrm{dl}$ & 79 & 18.2 \\
\hline Hho of the rosnondont & & $5-6 \mathrm{~g} / \mathrm{dl}$ & 91 & 21.0 \\
\hline HD\% or tile responduent & & $7-10 \mathrm{~g} / \mathrm{dl}$ & 148 & 34.2 \\
\hline & & above $10 \mathrm{~g} / \mathrm{dl}$ & 115 & 26.6 \\
\hline & & $<$ then normal & 104 & 24.0 \\
\hline LFTs of the respondent & & Normal & 296 & 68.4 \\
\hline & & more than normal & 33 & 7.6 \\
\hline & & 1 - 3 months & 92 & 21.2 \\
\hline Coctotionol month & & 4 - 5 months & 117 & 27.0 \\
\hline Gestational month & & $6-7$ months & 83 & 19.2 \\
\hline & & 8 - 9 months & 141 & 32.6 \\
\hline & & $<1$ year & 173 & 40.0 \\
\hline A crof locts child bom & & 1 year & 105 & 24.2 \\
\hline Age or last cnila born & & 2 years & 98 & 22.6 \\
\hline & & Above 2 years & 57 & 13.2 \\
\hline & & nuclear & 186 & 43.0 \\
\hline Type of family you baye? & & Joint & 169 & 39.0 \\
\hline 1ype or ramily you nave? & & Extended & 48 & 11.1 \\
\hline & & any other & 30 & 6.9 \\
\hline & & $<10,000$ & 146 & 33.7 \\
\hline Montbly income of the boucolold? & & $11,000-15,000$ & 208 & 48.0 \\
\hline Montniny income or the nousenord? & & $16,000-20,000$ & 48 & 11.1 \\
\hline & & Above 20,000 & 31 & 7.2 \\
\hline & & House wife & 263 & 60.7 \\
\hline Current status of the respondent & & Doing job & 126 & 29.1 \\
\hline & & Both A and B & 44 & 10.2 \\
\hline & & 2 times a day & 147 & 33.9 \\
\hline Fating babbits of the resnondent & & 3 times a day & 247 & 57.0 \\
\hline Eating habbits of the respondent & & 4 times a day & 30 & 6.9 \\
\hline & & More frequently & 9 & 2.1 \\
\hline
\end{tabular}




\section{Continued}

\begin{tabular}{|c|c|c|c|}
\hline \multirow{4}{*}{ Daily tea intake of the respondent } & Once a day & 159 & 36.7 \\
\hline & Twice a day & 189 & 43.6 \\
\hline & Thrice a day & 57 & 13.2 \\
\hline & More frequent & 28 & 6.5 \\
\hline \multirow{4}{*}{ You are eating fresh fruits, vegetables and milk } & Daily & 197 & 45.5 \\
\hline & 2 times week & 131 & 30.3 \\
\hline & Weekly & 62 & 14.3 \\
\hline & Very rare & 43 & 9.9 \\
\hline \multirow{2}{*}{ You are using any sort of iron supplement } & Yes & 229 & 52.9 \\
\hline & No & 204 & 47.1 \\
\hline \multirow{2}{*}{ Are you suffering from frequent nausea and vomiting } & Yes & 264 & 61.0 \\
\hline & No & 169 & 39.0 \\
\hline \multirow{3}{*}{ Your daily eating habits are } & Just like previous & 287 & 66.3 \\
\hline & Double then previous & 98 & 22.6 \\
\hline & Less than previous & 48 & 11.1 \\
\hline \multirow{2}{*}{ Do you know that pregnant women need for double diet } & Yes & 285 & 65.8 \\
\hline & No & 148 & 34.2 \\
\hline \multirow{3}{*}{ Your average hour of rest per day } & 5 - 6 hours & 201 & 46.4 \\
\hline & 7 - 8 hours & 147 & 33.9 \\
\hline & Above 8 hours & 85 & 19.6 \\
\hline \multirow{2}{*}{ Do you know about cheap alternatives of healthy diet? } & Yes & 282 & 65.1 \\
\hline & No & 151 & 34.9 \\
\hline \multirow{2}{*}{ Do you have previous history of miscarriage? } & Yes & 195 & 45.0 \\
\hline & No & 238 & 55.0 \\
\hline \multirow{2}{*}{ Are you suffering from any hemorrhagic disease (APH)? } & Yes & 205 & 47.3 \\
\hline & No & 228 & 52.7 \\
\hline \multirow{2}{*}{ Nature of work you daily done } & Light and normal & 307 & 70.9 \\
\hline & Exhaustive & 126 & 29.1 \\
\hline \multirow{2}{*}{ Are you suffering from any sort of stress or worry? } & Yes & 208 & 48.0 \\
\hline & No & 225 & 52.0 \\
\hline \multirow{2}{*}{ Do you think after attending regular visits to doctor you feel quite better than previous? } & Yes & 282 & 65.1 \\
\hline & No & 151 & 34.9 \\
\hline
\end{tabular}

Monthly income of the respondents were $<10,000$ (33.7\%), 11,000 - 15,000 (48\%) 16,000 - 20,000 (11.1\%) and above 20,000 (7.2\%). Majority of the women i.e. (60.7\%) were housewives while $29.1 \%$ doing job and $10.2 \%$ fall in other category. Daily eating habits of the respondents show that about $33.9 \%$ take meal twice a day while 57\% respondents enjoy it 3 times. Data shows that $6.9 \%$ respondents 4 times and $2.1 \%$ respondents take meal more frequently in a day. Similarly $36.7 \%$ of respondents take tea once in a day while $43.6 \%$ twice in a day whereas $13.2 \%$ thrice in a day and $6.5 \%$ take tea more than thrice time. $45.5 \%$ of the respondents eat fresh fruits, vegetables and milk daily, 30.3\% twice in a day, $14.3 \%$ weekly and $9.9 \%$ rarely. About 52.9\% women were using iron supplement and $47 \%$ said they have never used iron supplement. $61 \%$ of the women have suffered from nausea and vomiting. Average hour of the rest per day of the $46.4 \%$ of women were 5 to 6 hours, 33.9\% respondents were 7 - 8 hours and 19.6\% respondents above 8 hour. The women who had previous history of miscarriage were about $45 \%$. About $47.3 \%$ of the women were suffered in hemorrhagic disease (APH).

The Table 5 shows the results of multiple logistic regression models with odd ratios and their 95\% confidence interval. The logistic regression model was performed to check the potential of anemia in the presence of different risk factors. To perform this the variable eating double diet of the respondent was considered as binary response namely (yes, no) and all the remaining were considered as independent variables at different levels as can be seen from Table 5. The results showed that anemia is more dominant in the age group 21 - 25 and above 35 years that is 1.067 times and 1.817 times more likely to have anemia with $95 \%$ C-I (0.210 and $5.429)$ and (0.485 and 6.799) respectively than the reference age group that is 15 - 20 the age group 26 - 30 and 
Table 5. Prevalence rate of Anemia and effects of different potential risk factors in pregnant women in the population of Muzaffarabad Azad Kashmir.

\begin{tabular}{|c|c|c|c|c|}
\hline I & & OR & $(95 \% \mathrm{CI})$ & \\
\hline \multirow{5}{*}{ Age } & $15-20^{r}$ & 1 & & \\
\hline & $21-25$ & 1.067 & 0.210 & 5.429 \\
\hline & $26-30$ & 0.447 & 0.101 & 1.986 \\
\hline & $31-35$ & 0.403 & 0.110 & 1.469 \\
\hline & Above 35 & 1.817 & 0.485 & 6.799 \\
\hline \multirow{4}{*}{ Age at the time of marriage } & 16 - 20 years & 3.945 & 0.294 & 52.985 \\
\hline & 21 - 25 years & 2.316 & 0.192 & 27.932 \\
\hline & 26 - 30 years & 4.179 & 0.347 & 50.320 \\
\hline & Above 30 years & 0.714 & 0.049 & 10.460 \\
\hline \multirow{4}{*}{ Education of the respondent } & Intermediate and above ${ }^{\mathrm{r}}$ & 1 & & \\
\hline & Primary & 1.179 & 0.009 & 156.200 \\
\hline & Middle & 0.637 & 0.009 & 162.826 \\
\hline & Matric & 0.489 & 0.004 & 67.561 \\
\hline \multirow{3}{*}{ No. of children you have } & Above $7^{r}$ & 1 & & \\
\hline & $1-3$ & 0.285 & 0.099 & 0.820 \\
\hline & $4-7$ & 0.465 & 0.163 & 1.325 \\
\hline \multirow{4}{*}{ Type of pregnancy } & quarterplet $^{\mathrm{r}}$ & 1 & & \\
\hline & Single & 0.306 & 0.060 & 1.569 \\
\hline & Twin & 0.146 & 0.026 & 0.815 \\
\hline & Triple & 0.134 & 0.022 & 0.820 \\
\hline \multirow{2}{*}{$\mathrm{Hb} \%$ of the respondent } & Above $10 \mathrm{~g} / \mathrm{dl}^{\mathrm{r}}$ & 1 & & \\
\hline & $5-6 \mathrm{~g} / \mathrm{dl}$ & 2.221 & 0.679 & 7.263 \\
\hline \multirow{3}{*}{ LFTs of the respondent } & $<$ then normal $^{\mathrm{r}}$ & 1 & & \\
\hline & Normal & 1.695 & 0.710 & 4.047 \\
\hline & More then normal & 3.852 & 0.894 & 16.596 \\
\hline \multirow{4}{*}{ Gestational month } & $1-3$ months $^{r}$ & 1 & & \\
\hline & 4 - 5 months & 1.314 & 0.434 & 3.978 \\
\hline & 6 - 7 months & 0.728 & 0.253 & 2.093 \\
\hline & 8 - 9 months & 0.765 & 0.257 & 2.281 \\
\hline \multirow{4}{*}{ Age of last child born } & Above 2 year $^{r}$ & 1 & & \\
\hline & 1 year & 1.711 & 0.399 & 7.341 \\
\hline & 2 years & 1.284 & 0.304 & 5.421 \\
\hline & $<1$ year & 2.224 & 0.552 & 8.952 \\
\hline \multirow{4}{*}{ Type of family you have } & nuclear $^{\mathrm{r}}$ & 1 & & \\
\hline & Joint & 0.871 & 0.368 & 2.064 \\
\hline & Extended & 0.788 & 0.213 & 2.923 \\
\hline & any other & 0.080 & 0.014 & 0.447 \\
\hline \multirow{4}{*}{ Monthly income of the household? } & Above $20,000^{r}$ & 1 & & \\
\hline & $11,000-15,000$ & 3.623 & 0.678 & 19.361 \\
\hline & $16,000-20,000$ & 2.158 & 0.441 & 10.563 \\
\hline & $<10,000$ & 2.296 & 0.385 & 13.677 \\
\hline \multirow{3}{*}{ Current status of the respondent } & House wife ${ }^{r}$ & 1 & & \\
\hline & Doing job & 0.929 & 0.224 & 3.844 \\
\hline & Both A and B & 1.155 & 0.240 & 5.555 \\
\hline
\end{tabular}




\section{Continued}

Eating habits of the respondent

Daily tea intake of the respondent

You are eating fresh fruits, vegetables and milk

You are using any sort of iron supplement

Are you suffering from frequent nausea and vomiting

Your daily eating habits are

Your average hour of rest per day

Do you know about cheap alternatives of healthy diet?

Do you have previous history of miscarriage?

Are you suffering from any hemorrhagic disease (APH)?

Nature of work you daily done

Are you suffering from any sort of stress or worry?

Do you think after attending regular visits to doctor you feel quite better then previous?
2 times a day ${ }^{r}$

3 times a day

4 times a day

More frequently

Once a day ${ }^{\mathrm{r}}$

Twice a day

Thrice a day

More frequent Daily $^{r}$

2 times week

Weekly

Very rare

Yes $^{\mathrm{r}}$

No

Yes $^{\mathrm{r}}$

No

Double than previous ${ }^{\mathrm{r}}$

Just like previous

Less then previous

$5-6$ hours $^{\mathrm{r}}$

7 - 8 hours

Above 8 hours

yes $^{\mathrm{r}}$

No

$\mathrm{No}^{\mathrm{r}}$

Yes

$\mathrm{No}^{\mathrm{r}}$

$$
\text { Yes }
$$

Light and normal ${ }^{\mathrm{r}}$

Exhaustive

Yes $^{\mathrm{r}}$

No

Yes $^{\mathrm{r}}$

No
1

0.356

0.044

2.913

0.252

0.031

2.075

2.905

1

$2.473 \quad 0.569 \quad 10.757$

$\begin{array}{lll}1.555 & 0.330 \quad 7.318\end{array}$

$5.808 \quad 1.181 \quad 28.565$

1

0.467

0.445

$0.112 \quad 1.953$

$0.099 \quad 2.005$

$\begin{array}{lll}0.433 & 0.090 \quad 2.075\end{array}$

1

$0.320 \quad 0.146 \quad 0.704$

1

$0.305 \quad 0.143 \quad 0.652$

1

$2.415 \quad 0.652 \quad 8.948$

$\begin{array}{lll}3.671 & 0.868 \quad 15.522\end{array}$

1

$1.993 \quad 0.558 \quad 7.112$

$0.324 \quad 0.078 \quad 1.349$

1

$0.055 \quad 0.023 \quad 0.131$

1

$1.258 \quad 0.103 \quad 0.647$

1

$1.529 \quad 0.592 \quad 3.949$

1

$\begin{array}{lll}1.961 & 0.805 \quad 4.779\end{array}$

1

$0.317 \quad 0.140 \quad 0.718$

1

$\begin{array}{lll}0.606 & 0.282 \quad 1.305\end{array}$
31 - 35 having less chances of anemia as the odd ratio is less than 1 i.e. OR $(0.447,0.403)$ and 95\% C-I (0.101 to1.986) and (0.110 to 1.469$)$ respectively. Similarly the respondents age at the time of marriage was also showed that the occurrence of anemia in the age group $16-20$ years, 21 - 25 years, 26 - 30 years were 3.945 times, 2.316 times and 4.179 times more as compared with age group less than 15 years and the value of odd ratio of age group above 30 years is 0.714 which is also positively linked with anemia. The 95\% C-I for these age groups are shown in the above Table 5. The education of the respondent is also a significant determinant it can be observed that are illiterate and primary were 1.191 times and 1.179 times more likely to have anemia as compared with educated women that is intermediate and matric. The 95\% C-I for different education level were also showed in the above table. The number of children and type of pregnancy also showed positive association with anemia. LFT of the women was also observed as a strong determinant for anemia that is the women having normal and more than normal LFT were 1.695 and 3.852 times more chances to have suffered in anemia as compared with women less than normal LFT. The 95\% C-I was also showed. Another dominant risk factor of the anemia was $\mathrm{Hb} \%$ of the respondents it was observed that women having $\mathrm{Hb} \%$ level 5 - $6 \mathrm{~g} / \mathrm{dl}, 7$ - $10 \mathrm{~g} / \mathrm{dl}$ and 3 - 4 g/dl were 2.221 times,1.364 times 1.220 times more likely to have anemia as compared with above $10 \mathrm{~g} / \mathrm{dl} \mathrm{Hb} \%$ level, the 95\% C-I was also calculated. Gestational months and type of the family of the respondents were also showed positive link with anemia. Monthly income of the respondents household was also observed as a strong indi- 
cator for the occurrence of anemia the results showed that the house hold income 11,000 - 15,000, 16,000 20,000 and $<10,000$ were 3.623 times, 2.158 and 2.296 times more chances of anemia as compared with respondents income above 20,000 so income is a very important factor for anemia. The 95\% C-I for different income level was also shown in Table 5. The results revealed that current status of the respondent, daily eating habits, daily tea intake, use of fresh vegetables, fruits, use of iron supplement and suffered frequently in nausea and vomiting were also showed positive association with anemia. It was observed that the women having diet less than previous and just like previous were 3.671 times and 2.415 times more chances to have anemia as compared with women having diet double than previous. Average hour of rest per day and respondent who know cheap alternative of healthy diet were also important for anemia. The women having previous history of miscarriage were 1.258 times more likely to have anemia as compared with women have no miscarriage. Similarly the women who ever suffered in the disease hemorrhagic disease were 1.529 times more chances of anemia as compared with women who never suffered in such disease. It was observed that the women who done exhaustive work 1.961 times more likely to be anemia as compared with women who have normal and light work, so nature of the work is also a vital indicator for the occurrence of anemia. The results showed that the women who suffered in any worry or stress and who regular visited to the doctor were also positively associated with anemia.

The Figures $\mathbf{2}$ and $\mathbf{3}$ showed the probabilities of all the independent variables in the above Table 4 and it can be observed that all the variables are positively associated with anemia.

\section{SUMMARY AND CONCLUSION}

The main aim of the study was to find out the relationship of education with increase rate of anemia and to find out the most common causes of anemia in pregnant

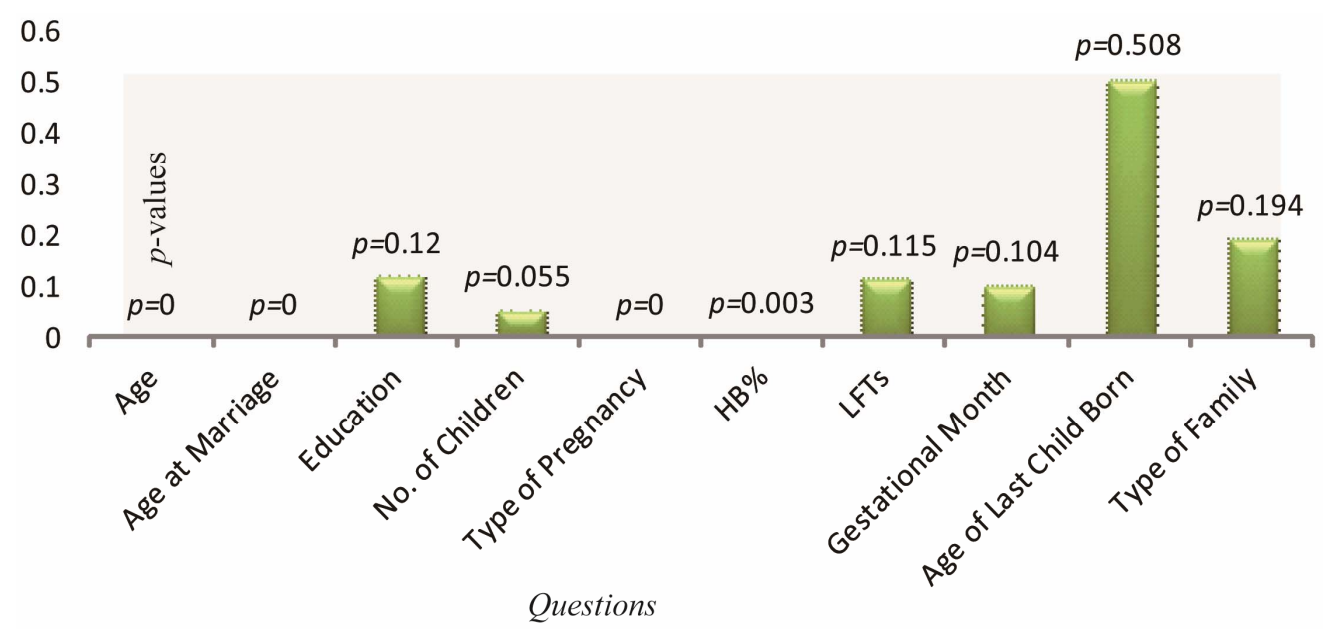

Figure 2. Causes of Anemia in pregnant women.

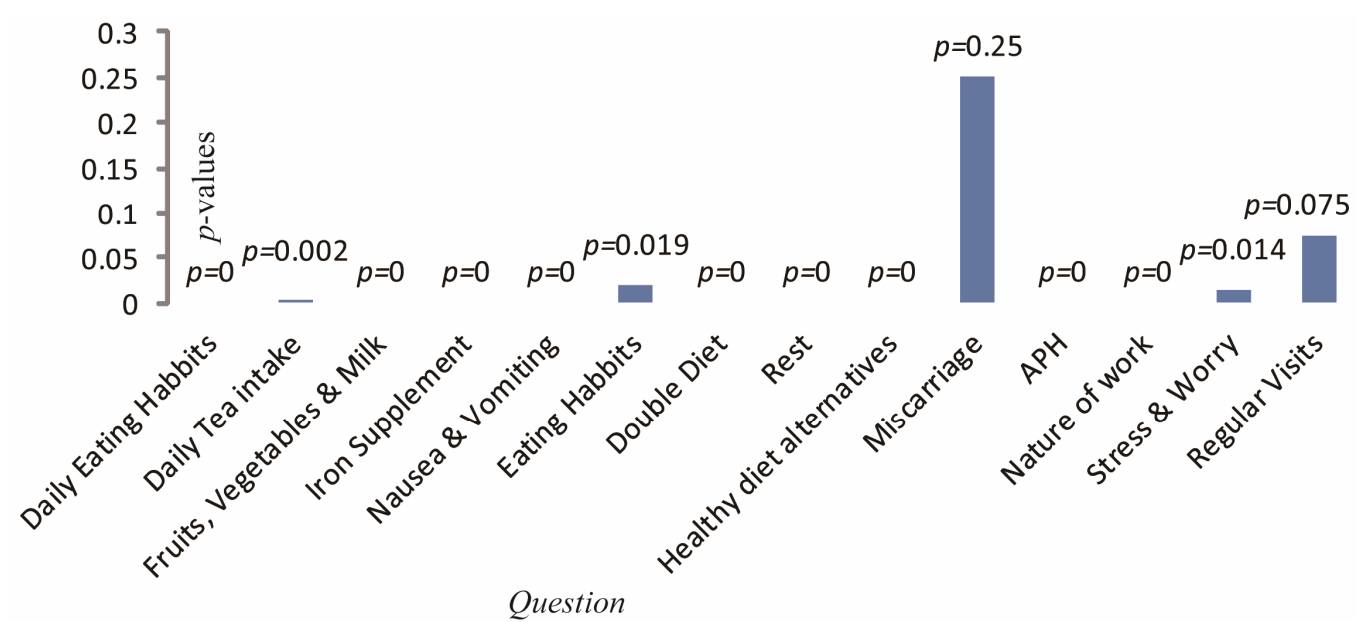

Figure 3. Causes of Anemia with respect to daily activities and food. 
women. The sample of 433 pregnant women was selected from Abbas Institute of Medical Sciences (AIMS) Muzaffarabad. It was observed that there is linear but negative relationship between education and anemia. By using chi-square, it was found that all the factors are highly associated with $\mathrm{Hb} \%$ of the women except three that are suffered in frequent nausea and vomiting, previous history of miscarriage and suffering of any hemorrhagic disease. So $\mathrm{Hb} \%$ of the respondent is a strong indicator of the anemia. By the results of odd ratios, there were found that the anemia is most prevalent in the age group 21 - 25 years $(\mathrm{OR}=1.067)$, similarly the age at the time of marriage the values of odd ratio at different age group $16-20(\mathrm{OR}=3.945), 16-20(\mathrm{OR}=2.316)$ and $26-30(\mathrm{OR}=4.179)$ shows that how strongly associated age at the time of marriage. The values of odd ratios for education level i.e illiterate and primary $(\mathrm{OR}=$ 1.191 , OR $=1.179$ ) times more likely to have anemia. The results showed that the women having $\mathrm{Hb} \% 3-4$ $\mathrm{g} / \mathrm{dl}, 5-6 \mathrm{~g} / \mathrm{dl}$ and $710 \mathrm{~g} / \mathrm{dl}(\mathrm{OR}=2.221$, OR = 1.384, $\mathrm{OR}=1.220$ ) times more chances of anemia as compared with women having above $10 \mathrm{~g} / \mathrm{dl}$. Similarly the number of children, gestational month, LFT, age of last children, type of family and eating habits are also associated with anemia. Income of the house hold was also observed as a strong factor of anemia the results of odd ratios showed that the house hold income $<10,000(\mathrm{OR}=3.623)$, $11,000-15,000(\mathrm{OR}=2.158)$ and $16,000-20,000(\mathrm{OR}=$ 2.296) times more chances of anemia as compared with having income above 20,000. The results showed that average hour of rest per day, cheap alternative of healthy diet, previous history of miscarriage, suffered in hemorrhagic disease, nature of the work, suffered in stress or worry and regular visited to the doctor also showed the significant results. It can be concluded that the proper education of the women can help them to get awareness about the causes of anemia. Anemia can also be prevented by the intervention of low cost iron supplement.

Moreover at government or at semi government level the well trained lady health workers should be involved to launch a campaign to create awareness about the causes of anemia. Mass media or print media can also campaign to raise the bar of knowledge in women. Socio economic conditions in our poor society are also one of the main causes of anemia. In our knowledge this is the first research on that particular issue in A.J. \& K. Muzaffarabad.

\section{REFERENCES}

[1] Karine, T. and Jennifer, F.F. (2007) An update on Anemia in less developed countries. The American Journal of Tropical Medicine and Hygiene, 77, 44-51. http://www.ajtmh.org/content/77/1/44.abstract

[2] World Health Organization/United Nations University/ UNICEF (2001) Iron deficiency anemia, assessment, prevention and control: A guide for program managers. WHO, Geneva, 114.

[3] World Health Organization (1997) WHO Global Database. WHO, Geneva.

[4] Ijaz-ul-Haque, T., Ahsanullah, M., Sohail, S. and Zara, A. (2011) Anemia in pregnancy related risk factor in underdeveloped area. Professional Medical Journal, 18, 1-4. http://www.theprofesional.com/article/2011/vol-01/001-P rof-1679.pdf

[5] Ilyas, M.M.Q., Shujaat, A.K., Kalsoom, F., Ghulam, M., Saira, A., Sobia, N., Tauqir, S.A.S., Amara, M., Haider, S. S., Malik, A., Nisar, A., Rehmana, R., Rabia, R. and Hassham, H.M.A. (2012) Prevalence of iron deficiency in adult population: A case study from Khyber Pakhtunkhwa (KPK), Pakistan. International Journal of Physical Sciences, 7, 1874-1877.

[6] Yasir, P.K., Shereen, Z.B., Shama, M. and Zulfiqar, A.B. (2009) Maternal health and survival in Pakistan: Issues and options. Journal of Obstetrics and Gynaecology Canada, 31, 920-929.

[7] Riffat, J. and Ayesha, K. (2008) Severe anemia \& adverse pregnancy outcome. Department of Obstetrics \& Gynecology Unit V, Lyari General Hospital Dow University of Health Sciences Karachi. Journal of Surgery Pakistan (International), 13, 147-150.

[8] Sabah, S., Ramzan, M. and Fatima, I. (2010) Iron deficiency anemia: Role of nutritional deprivation among female patients of reproductive age group. Professional Medical Journal, 17, 686-690.

[9] Linda, A.A. (2004) Anemia in pregnancy is preventable. Ghana Web.

http://www.ghanaweb.com/GhanaHomePage/features/arti kel.php?ID=56859 